\title{
Testis-sparing surgery: Experience in 13 patients with oncologic and functional outcomes
}

\author{
Murat Keske ${ }^{1}$; Abdullah Erdem Canda ${ }^{2}$; Ali Fuat Atmaca ${ }^{3}$; Ozer Ural Cakici ${ }^{4}$; Muhammed \\ Ersagun Arslan ${ }^{5}$; Davut Kamaci ${ }^{5}$; Mevlana Derya Balbay ${ }^{2}$ \\ ${ }^{1}$ University of Health Sciences, Kayseri Training and Research Hospital, Department of Urology, Kayseri; \\ ${ }^{2}$ Koc University, School of Medicine, Department of Urology, Istanbul; ${ }^{3}$ Yildirim Beyazit University, School of \\ Medicine, Department of Urology; ${ }^{4}$ Yenimahalle Training and Research Hospital, Department of Urology, \\ Ankara; ${ }^{5}$ Ankara Ataturk Training and Research Hospital, Department of Urology, Ankara; Turkey
}

Cite as: Can Urol Assoc J 2018 August 30; Epub ahead of print.

http://dx.doi.org/10.5489/cuaj.5379

Published online August 30, 2018

\section{Abstract}

Introduction: We present oncological and functional outcomes of patients who underwent testis-sparing surgery (TSS).

Methods: Overall, 13 patients were included. Mean patient age was $29.9 \pm 12.5$ years. In five patients, TSS was performed for sequential bilateral testicular tumours. One patient underwent concurrent left radical orchiectomy and right TSS. In eight patients with normal contralateral testis, seven underwent left and one underwent right TSS.

Results: Mean pathological tumour size was $14.6 \pm 12.5 \mathrm{~mm}$. Intraoperative frozen section evaluation of the mass was performed in eight patients that revealed benign lesions. No intraoperative tumour bed biopsies were taken in this patient group. Regarding the remaining five patients, intraoperative tumour bed biopsies were taken and testicular intraepithelial neoplasia (TIN) was reported in two (40\%) patients; no local testicular radiotherapy was given postoperatively. Tumour pathology was malignant in all but one lesion, including Leydig cell tumour $(n=1)$, seminoma( $n=2)$, embryonal carcinoma $(n=1)$, and adenomatoid tumour ( $\mathrm{n}=1$ ). During 47.2 \pm 22.5 months of followup, local recurrence was detected in one patient who underwent radical orchiectomy. No additional local recurrence or systemic metastasis was identified in other patients with malignant lesions. For patients with malignant tumours, of the three patients with a normal preoperative testosterone levels, testosterone level was normal in one patient (with no erectile dysfunction [ED]) and was decreased in two patients (with ED) following TSS. No ED was reported in the nine patients with benign lesions.

Conclusions: In carefully selected cases, TSS appears to be a safe, feasible procedure with adequate cancer control that could preserve sexual function. 


\section{Introduction}

Testicular neoplasms are the most common solid organ tumors in males aged between 15 and 35 years. Radical inguinal orchiectomy has been considered as the standard treatment since it was first described. ${ }^{1,2}$ Testis sparing surgery (TSS) is reported to be feasible and applicable in bilateral tumors, and patients with single testis, while the tumor volume is less than $30 \%$ of the total testicular volume, and the preoperative testosterone levels are within normal limits. ${ }^{2}$ Organ sparing surgery carries psychological and endocrine advantages that would avoid erectile dysfunction (ED) and fertility issues.

In the contemporary practice, small and incidental testicular tumors are more widely observed because of the frequent usage of the radiological imaging modalities. Mainly, use of the ultrasound in the primary evaluation of the scrotal symptoms has led to high incidence in the detection of small, mostly benign, testicular masses. ${ }^{3}$ In this study, we aimed to evaluate the oncological and functional outcomes of the patients whom we performed TSS.

\section{Methods}

Overall, 13 patients were included who underwent TSS between January of 2008 and December of 2017.

Inclusion criteria and indications for TSS followed recommendations of the European Association of Urology (EAU) guidelines and German Cancer Study Group that included patients with malignant tumors in solitary testis or bilateral testicular tumors with small lesions without radiological rete testis invasion 4 , tumor volume $<30 \%$ of overall testicular volume 2, tumor location suitable for surgical excision respecting oncological principles5, tumors that are not palpable and are identified with ultrasound6, testicular mass lesions with $<1.5 \mathrm{~cm}$ in size and with normal serum tumor markers that have the probability of $>60 \%$ being benign7,8 and in children with small sized lesions that are suitable for TSS that have a higher probability of being benign.9,10

TSS was performed using a classical high-inguinal incision, which involves the early clamping of the spermatic cord. Cold-ischemia was induced using sterile ice-slush for 15 minutes. Tunica vaginalis was incised, the testicular mass was excised and frozen sections of the mass and the tumor bed were obtained in selected cases. Intraoperative ultrasound was used to locate the mass if required. Tunica vaginalis was closed with absorbable sutures in continued fashion, if the outcome of the frozen section evaluation was compatible with benign tumor. In patients with solitary testis or metachronal ipsilateral tumors, tunica vaginalis was closed if the tumor bed frozen section biopsies were benign or the frozen section of the mass was reported as malignant.

Patient charts were reviewed in terms of history, preoperative and postoperative ultrasound reports, postoperative computerized tomography (CT) scan of the abdomen and the thorax, preoperative and postoperative blood tests and, testosterone levels.

\section{Results}

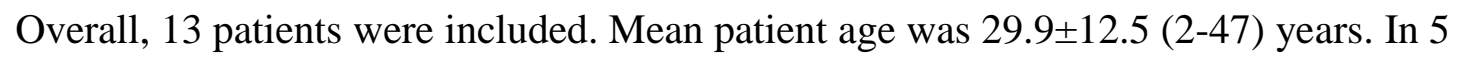
patients, TSS was performed for sequential bilateral testicular tumors. One patient underwent concurrent left radical orchiectomy and right TSS. In the other 8 patients, contralateral testis 
was normal and of those 7 underwent concurrent left and 1 underwent concurrent right partial orchiectomy.

Palpable testicular mass with scrotal pain was the initial symptom in 2 patients, while 7 patients were admitted with a painless testicular mass. Recurrent testicular mass was noticed during the follow-up of 3 patients by scrotal ultrasound, and in 1 patient by the elevated serum tumor marker levels. Demographic and clinic data of the study cohort is presented in the Table 1.

Mean tumor size was $14.6 \pm 12.5 \mathrm{~mm}$. Intraoperative frozen section evaluation of the mass was performed in patients with benign lesions $(n=8)$ including adenomatoid tumor $(n=1)$, epidermoid cyst $(n=3)$, ischemic infarct $(n=1)$, sperm granuloma $(n=1)$, tunica albuginea cyst $(n=1)$ and hyaline changes without tumor $(n=1)$. No intraoperative tumor bed biopsies were taken in this patient group.

In the regarding remaining 5 patients who had all but one malignant lesions included leydig cell tumor $(n=1)$, seminoma $(n=2)$, embryonal carcinoma $(n=1)$ and adenomatoid tumor $(n=1)$. Intraoperative tumor bed biopsies were taken and testicular intraepithelial neoplasia (TIN) was reported in 2 (\%40) patients in the tumor bed biopsies. No local testicular radiotherapy (RT) was given postoperatively in these 2 patients because both patients refused RT. These patients had history of contralateral radical inguinal orchiectomy, and the mean time to the recurrence in the solitary testis was $42.5 \pm 21.7$ (24-74) months.

No intraoperative, perioperative (0-30 days) or postoperative (31-90 days) complication was identified in any patient.

Mean follow-up time was 47.2 \pm 22.5 (24-80) months. No re-do TSS was performed in any patient. Local recurrence was detected in 1 patient. This patient initially underwent right radical inguinal orchiectomy that revealed classical seminoma and received postoperative radiotherapy. During follow-up (6 years later), a left testicular lesion was identified and TSS was performed that revealed seminoma with a $12 \mathrm{~mm}$ size. Postoperative chemotherapy was given. During follow-up, a 6.5x8.5 mm sized left testicular lower pole lesion was detected and left inguinal orchiectomy was performed. Pathology revealed intra-tubular germ cell neoplasia. Tumor markers were normal due to a follow-up of 80 months and no additional therapy was given. Patient received testosterone replacement. During follow-up, local recurrence or systemic metastasis was not observed in other patients with malignant lesions.

For patients with malignant tumors, of the 3 patients with a normal preoperative testosterone levels, serum testosterone level was normal in 1 patient with no erectile dysfunction (ED) and was decreased in 2 patients with ED after the TSS procedure. No ED was reported in 9 patients with benign lesions.

\section{Discussion}

Despite the historical acceptance of radical inguinal orchiectomy in the standard treatment of the testicular tumors, TSS has been used more widely in the contemporary management of the small testicular masses.

The volume, dimensions and the location of the mass are regarded as the most important factors in order to decide to perform organ-sparing approach in testicular tumors. Giannarini et al. reported that two thirds of the testicular masses under $2 \mathrm{~cm}$ are benign, and they suggested that the TSS could be considered in these patients. ${ }^{6}$ Another study reported a 
higher incidence of malignancy in testicular masses that are larger than $1.5 \mathrm{~cm}$ in size, and proposed classifying the testicular tumors smaller than $1.5 \mathrm{~cm}$ as "small”, while classifying testicular tumors smaller than $1 \mathrm{~cm}$ as "very small". ' Several previous papers reported even higher incidence of benign pathology (up to 60\%) of tumors in testicular masses smaller than $1.5 \mathrm{~cm}^{7,8}$

In our study, the mean tumor size was $14.6 \mathrm{~mm}$. Malign lesions were observed in 4 out of 13 patients (30.7\%), while benign lesions were observed in 9 out of 13 patients (69.3\%), which were compatible with the previous studies.

Benign testicular masses are also common in prepubertal era. TSS is reported to be feasible and applicable if the alpha-fetoprotein (AFP) levels are normal. ${ }^{11}$ In our series, testicular mass was noticed by the scrotal ultrasound scan in one patient who was 2 years old and laboratory tests revealed normal serum tumor markers. Pathological evaluation of the partial orchiectomy material showed hyalinized changes without any neoplastic growth.

Intratesticular germ cell neoplasia (ITGCN) is the precursor lesion of the germ cell tumors that can be seen in $80 \%$ of the normal appearing testicular tissue surrounding the germ cell tumors. ${ }^{12}$ Thus, low-dose postoperative radiotherapy is suggested while the final pathologic result is malignant. However, an evaluation that was irrelevant with the tumor size was reported in this study. Previously, we reported $20 \%$ of ITGCN existence in the normal appearing peri-tumoral testicular parenchyma in a large multicenter study. ${ }^{13}$

Benign lesions have no risk of the recurrence. ${ }^{13,14,15}$ TSS is a safe option in these tumors. It has also been shown that organ sparing surgery is a reasonable and reliable alternative for testicular tumors with benign tendency. ${ }^{16}$

Preservation of the testicular function holds importance in terms of preventing the postoperative erectile dysfunction (ED). ED is seen in 31.5\% of patients after radical orchiectomy. ${ }^{17}$ Postoperative hormonal therapy can be feasible, however, several possible side effects i.e. cardiologic, endocrine, immunologic, dermatologic effects, should be considered. ${ }^{18}$ Furthermore, exogenous androgens may fail because of the dysfunctional hypothalamic-hypophysis axis. In our study, ED was not observed in any of the patients with benign testicular mass and intact contralateral testicle. Performing partial orchiectomy in benign appearing testicular masses may prevent postoperative ED as well as avoiding hormone replacement.

Fertility is another issue to assess in the young population that is usually affected by testicular tumors. Some evidence is available in the literature on the disruptive effects of unilateral orchiectomy on the overall spermatogenesis. ${ }^{19}$ Liu et al. reported no significant changes between preoperative and postoperative sperm concentrations and motilities in 11 patients with TSS history due to benign testicular tumors. ${ }^{16}$ The risk of recurrence in the contralateral testis in patients with who had malign testicular tumors was reported to be between $1.8 \%$ and $2.8 \% .{ }^{20}$ The most common bilateral testicular tumor is seminoma that can present with metachronous metastasis in 4 years. ${ }^{21}$ Heindrich et al. reported the follow-up of 73 patients who were treated with TSS for metachronous testicular tumors. They further used radiotherapy in 46 patients because of the existence of ITGCN in peritumoral tissue. As a result, they reported a recurrence-free 7 years of follow-up in 72 (98\%) out of 73 patients. ${ }^{12}$ 
Selected published series on TSS is presented on Table 2. Among those series, Bojanic et al. reported that TSS was carried out in 24 patients, and local recurrence was detected in 7 cases. Five out of the seven patients were diagnosed with TIN and radical orchiectomy was performed. A re-do TSS procedures was carried out in remaining two patients. Chemotherapy protocol was initiated in one patient because of systemic disease. Overall survival rate was reported as $100 \% .^{22}$ Therefore, TSS was shown to be feasible without compromising survival rates with potential benefits.

In our study group, we also observed local recurrence in one patient that led to radical orchiectomy. By this approach, TSS was performed without compromising the oncological outcomes, particularly cancer free survival. Due to these results, we think that TSS can be performed in patients with germ cell tumors (GCT) and who are compatible with the close follow-up.

Bojanic et al. evaluated 28 patients with both benign and malign testicular lesions. During 40.9 weeks' follow-up, of the 10 GCT patients, only one patient had local recurrence, and this patient underwent radical orchiectomy. Contralateral tumor or distant metastasis were not observed in any patient in their cohort. Overall survival was reported to be $100 \%{ }^{23}$ Benign testicular tumors were observed in 18 patients, which is also compatible with our results.

Galosi et al. observed malign lesions in 6 out of 28 patients, whose tumor sizes were $15 \mathrm{~mm}$ or smaller. ${ }^{8}$ They also developed an algorithm proposing that the frozen sections can be avoided in lesions smaller than $8 \mathrm{~mm}$ in diameter. In our study, we did not observe any malign lesions in tumors smaller than $12 \mathrm{~mm}$, which is compatible with Galosi and coworker's results.

TSS can provide a long-time survival, even the cure. TSS is a sensible option considering the preservation of the fertility, avoidance of the hormonal replacement, improved cosmetics, and psychological advantages. However, this surgical approach should be performed in experienced centers. ${ }^{24}$

Patients who are considered for TSS should be informed about the possible benefits, and the risks of the approach. Furthermore, patients should be aware of the possibility of receiving adjuvant treatments, if needed. TSS may be more suitable rather than radical approach, in selected patients with small testicular tumors with benign appearance. 


\section{References}

1. Krege S, Beyer J, Souchon R, et al. European consensus conference on diagnosis and treatment of germ cell cancer: a report of the second meeting of the European Germ Cell Cancer Consensus Group. (EGCCCG): part I. Eur Urol. 2008;53(3):478-96.

2. Albers P, Albrecht W, Algaba F, et al. Guidelines on testicular cancer: 2015 update. Eur Urol 2015;68:105468. https://doi.org/10.1016/j.eururo.2015.07.044

3. Carmignani L, Gadda F, Gazzano G, et al. High incidence of benign testicular neoplasm diagnosed by ultrasound. J Urol 2003;170(5):1783-6.

4. Heidenreich A. Re: incidence of late-relapse germ cell tumor and outcome to salvage chemotherapy. Eur Urol 2006; 50:386-387.

5. Zuniga A, Lawrentschuk N, Jewett MA. Organ-sparing approaches for testicular masses. Nat Rev Urol 2010; 7:454-464.

6. Giannarini G, Dieckmann KP, Albers P, et al. Organ-sparing surgery for adult testicular tumours: a systematic review of the literature. Eur Urol 2010; 57:780-90.

7. Murat Keske MD, Abdullah Erdem Canda MD, Serdar Yalcin MD, et al. Is testissparing surgery safe in small testicular masses? Results of a multicentre study. Can Urol Assoc J 2017;11(3-4):E100-4. http://dx.doi.org/10.5489/cuaj.4016.

8. Andrea B. Galosi, Paola Fulvi, Andrea Fabiani, et al. Testicular sparing surgery in small testis masses: A multinstitutional experience, Arch Ital Urol Androl. 2016 Dec 30;88(4):320-24. doi: 10.4081/aiua.2016.4.320.

9. Rushton HG, Belman AB. Testis-sparing surgery for benign lesions of the prepubertal testis. Urol Clin N Am 1993; 20:27-37.

10. Giannarini G, Mogorovich A, Bardelli I, et al. Testis-sparing surgery for benign and malignant tumors: a critical analysis of the literature. Indian J Urol 2008; 24:467-474.

11. Lynn L. Woo, M.D., Jonathan H. Ross, M.D. The role of testis-sparing surgery in children and adolescents with testicular tumors. Urol Oncol. 2016 Feb;34(2):76-83. doi: 10.1016/j.urolonc.2015.05.019. Epub 2015 Jun 17.

12. Heidenreich A, Weissbach L, Holtl W, et al., DI, German Testicular Cancer Study G. Organ sparing surgery for malignant germ cell tumor of the testis. J Urol 2001; 166:2161-65.

13. Shilo Y, Zisman A, Raz O, et al. Testicular sparing surgery for small masses. Urol Oncol 2012; 30:188-91.

14. Carmignani L, Colombo R, Gadda F, et al. Conservative surgical therapy for leydig cell tumor. J Urol 2007; 178:507-11.

15. Gentile G, Brunocilla E, Franceschelli A, et al. Can testis-sparing surgery for small testicular masses be considered a valid alternative to radical orchiectomy? A prospective single-center study. Clin Genitourin Cancer 2013; 11:522-26.

16. Liu B, Su H, Cheng G, et al. Experiences and outcomes of organ-sparing surgery for testicular tumour with benign tendency. Can Urol Assoc J. 2015 Nov-Dec;9(1112):E785-8. doi: 10.5489/cuaj.2972. Epub 2015 Nov 4.

17. Pühse G, Wachsmuth JU, Kemper S, et al. Chronic pain has a negative impact on sexuality in testis cancer survivors. J Androl 2012;33:886-93. http://dx.doi.org/10.2164/jandrol.110.012500

18. Jan Felix Joseph and Maria Kristina Parr. Synthetic Androgens as Designer Supplements. Curr Neuropharmacol. 2015 Jan;13(1):89-100. doi: 10.2174/1570159X13666141210224756.

19. Ferreira U, Netto JN, Esteves SC, et al. Comparative study of the fertility potential of men with only one testis. Scand J Urol Nephrol 1991;25:255-9.

http://dx.doi.org/10.3109/00365599109024555 
20. Schaapveld M, van den Belt-Dusebout AW, Gietema JA, et al. Risk and prognostic significance of metachronous contralateral testicular germ cell tumours. Br J Cancer 2012; 107:1637-43.

21. Klatte T, de Martino M, Arensmeier K, et al. Management and outcome of bilateral testicular germ cell tumors: a 25-year single center experience. Int J Urol 2008; 15:821-26.

22. Bojanic N, Bumbasirevic U, Vukovic I, et al. Testis sparing surgery in the treatment of bilateral testicular germ cell tumors and solitary testicletumors: A single institution experience. J Surg Oncol. 2015 Feb;111(2):226-30. doi: 10.1002/jso.23777. Epub 2014 Sep 5.

23. Bojanic N, Bumbasirevic U, Bojanic G, et al. Testis sparing surgery for treatment of small testicular lesions: Is it feasible even in germ cell tumors? J Surg Oncol. 2017 Mar;115(3):287-90. Doi: 10.1002/jso.24502. Epub 2017 Feb 13.

24. Djaladat H. Organ-sparing surgery for testicular tumours. Curr Opin Urol. 2015 Mar;25(2):116-20.doi:10.1097/MOU.0000000000000150. 


\section{Testis-sparing surgery}

\section{Figures and Tables}

\begin{tabular}{|c|c|c|c|c|c|c|c|c|c|c|c|c|c|c|c|}
\hline Patient & $\begin{array}{c}\text { Previous } \\
\text { operation }\end{array}$ & Side & $\begin{array}{l}\text { Preop } \\
\text { AFP }\end{array}$ & $\begin{array}{l}\text { Preop } \\
\text { B-hcg }\end{array}$ & $\begin{array}{l}\text { Histological } \\
\text { tumour type }\end{array}$ & $\begin{array}{c}\text { Tumour } \\
\text { size }(\mathrm{mm})\end{array}$ & CIS & Treatment & $\begin{array}{c}\text { Postop } \\
\text { AFP }\end{array}$ & $\begin{array}{l}\text { Postop } \\
\text { B-hcg }\end{array}$ & $\begin{array}{c}\text { Local } \\
\text { recurrence }\end{array}$ & $\begin{array}{l}\text { Vascularization } \\
\text { at Doppler US }\end{array}$ & Preop T & Postop T & ED \\
\hline 1 & $\begin{array}{c}\text { Left radical } \\
\text { orchiectomy }\end{array}$ & $\mathrm{R}$ & 3.1 & 0.1 & $\begin{array}{l}\text { Leydig cell } \\
\text { tumour }\end{array}$ & 34 & No & TSS & - & & No & - & 4.52 & 3.83 & - \\
\hline 2 & $\begin{array}{c}\text { Left radical } \\
\text { orchiectomy }\end{array}$ & $\mathrm{R}$ & 1.4 & 0.1 & $\begin{array}{l}\text { Embryonal } \\
\text { carcinoma }\end{array}$ & 12 & No & TSS & 1.3 & 0.72 & No & - & 2.47 & 1.86 & + \\
\hline 3 & $\begin{array}{c}\text { Right } \\
\text { radical } \\
\text { orchiectomy }\end{array}$ & $\mathrm{L}$ & 1.7 & 0.1 & $\begin{array}{l}\text { Seminoma+ } \\
\text { ITGCN }\end{array}$ & 12 & Yes & $\begin{array}{c}\mathrm{TSS}+\mathrm{RT}+\mathrm{K} \\
\mathrm{T}\end{array}$ & 2.2 & 0.47 & Yes & Normal & 1.6 & 1.12 & + \\
\hline 4 & & B & 5.6 & 1.84 & Seminoma & 40 & Yes & TSS & 5.6 & 0.76 & No & Normal & 3.34 & 1.62 & + \\
\hline 5 & $\begin{array}{c}\text { Right } \\
\text { radical } \\
\text { orchiectomy }\end{array}$ & $\mathrm{L}$ & 2.4 & 0.1 & $\begin{array}{l}\text { Adenomatoid } \\
\text { tumour }\end{array}$ & 8 & No & TSS & 1.9 & 0.1 & No & Normal & - & - & - \\
\hline 6 & - & $\mathrm{L}$ & 1.7 & 0.1 & $\begin{array}{c}\text { Epidermoid } \\
\text { cyst }\end{array}$ & 20 & No & TSS & - & - & No & Normal & - & - & - \\
\hline 7 & - & $\mathrm{L}$ & 1.6 & 0.1 & $\begin{array}{l}\text { Epidermoid } \\
\text { cyst }\end{array}$ & 10 & No & TSS & - & - & No & Normal & - & - & - \\
\hline 8 & - & $\mathrm{L}$ & 3.0 & 0.1 & $\begin{array}{l}\text { Ischemic } \\
\text { infarct }\end{array}$ & 5 & No & TSS & 3.19 & 0.1 & No & Normal & - & - & - \\
\hline 9 & - & $\mathrm{L}$ & 1.6 & 0.1 & $\begin{array}{c}\text { Sperm } \\
\text { granuloma }\end{array}$ & 5 & No & TSS & - & - & No & Normal & - & - & - \\
\hline 10 & - & $\mathrm{L}$ & 23.0 & 2 & $\begin{array}{c}\text { Hyaline } \\
\text { changes } \\
\text { without } \\
\text { tumour }\end{array}$ & 15 & No & TSS & - & - & No & Normal & - & - & - \\
\hline 11 & - & $\mathrm{L}$ & 2.0 & 0.1 & $\begin{array}{c}\text { Tunica } \\
\text { albugenia cyst }\end{array}$ & 5 & No & TSS & - & - & No & Normal & - & - & - \\
\hline 12 & - & $\mathrm{R}$ & 2.2 & 0.1 & $\begin{array}{l}\text { Adenomatoid } \\
\text { tumour }\end{array}$ & 20 & No & TSS & - & - & No & Normal & 4.95 & 3.9 & - \\
\hline 13 & - & $\mathrm{L}$ & 1.8 & 0.1 & $\begin{array}{l}\text { Epidermoid } \\
\text { cyst }\end{array}$ & 10 & No & TSS & 1.77 & 0.1 & No & Normal & 4.12 & 3.82 & - \\
\hline
\end{tabular}




\section{Testis-sparing surgery}

\begin{tabular}{|c|c|c|c|c|c|c|c|c|c|c|}
\hline Study & $\begin{array}{c}\text { Age } \\
\text { (mean) }\end{array}$ & Years & $\begin{array}{c}\text { No. of } \\
\text { pts }\end{array}$ & Synchronous & Metachronous & $\begin{array}{c}\text { Tumour } \\
\text { size, mm } \\
\text { (mean) }\end{array}$ & $\begin{array}{l}\text { Tumour } \\
\text { markers }\end{array}$ & No. of benign tumours & $\begin{array}{l}\text { No. of malign } \\
\text { tumours }\end{array}$ & TIN \\
\hline $\begin{array}{l}\text { Gentile et } \\
\mathrm{al}^{15}\end{array}$ & $44.3 \pm 18.7$ & $\begin{array}{l}2009- \\
2012\end{array}$ & 15 & Normal col & ralateral testis & $\begin{array}{c}0.95 \\
\pm 0.44\end{array}$ & Normal & $\begin{array}{c}\text { Dermoid cyst } \\
\text { Leydig cell tumour (5); } \\
\text { epidermoid cyst (1); } \\
\text { inflammation (2); } \\
\text { hematoma (1); abscess(1); } \\
\text { Sertoli cell tumour (1); } \\
\text { adenomatoid tumour (1) } \\
\end{array}$ & $\begin{array}{c}\text { Low-grade } \\
\text { fibromyxoid } \\
\text { liposarcoma (1); } \\
\text { Seminoma (1) }\end{array}$ & 2 \\
\hline \multirow{2}{*}{$\begin{array}{l}\text { Yaniv } \\
\text { Shilo et al } \\
13\end{array}$} & \multirow[t]{2}{*}{ NR } & \multirow[t]{2}{*}{$\begin{array}{l}1994- \\
2009\end{array}$} & \multirow[t]{2}{*}{16} & 2 & & NR & \multirow[t]{2}{*}{ NR } & \multirow{2}{*}{$\begin{array}{l}\text { Leydig cell tumour (4); } \\
\text { epidermoid cyst (2); } \\
\text { adenomatoid tumour (1) } \\
\text { cyst (1); Sertoli cell tumour } \\
\text { (1); multilocular cyst (1); } \\
\text { focal fibrosis (1) }\end{array}$} & \multirow{2}{*}{$\begin{array}{l}\text { Seminoma (3); } \\
\text { embryonal carcinoma } \\
\text { (1); teratoma (1) }\end{array}$} & \multirow[t]{2}{*}{ NR } \\
\hline & & & & 14 normal c & ntralateral testis & & & & & \\
\hline \multirow{2}{*}{$\begin{array}{l}\text { Bojanic et } \\
\mathrm{al}^{22}\end{array}$} & \multirow[t]{2}{*}{$29.58 \pm 8.15$} & \multirow{2}{*}{$\begin{array}{c}1996- \\
2013\end{array}$} & \multirow[t]{2}{*}{24} & & 12 & \multirow[t]{2}{*}{ NR } & \multirow{2}{*}{$\mathrm{NR}$} & - & \multirow{2}{*}{$\begin{array}{l}\text { Seminoma (16); non- } \\
\text { seminoma (7); } \\
\text { Leydigeoma (1) }\end{array}$} & \multirow[t]{2}{*}{9} \\
\hline & & & & 3 solit & stis tm & & & & & \\
\hline \multirow{2}{*}{$\begin{array}{l}\text { Bianjiang } \\
\text { Liu et al }\end{array}$} & \multirow[t]{2}{*}{26} & \multirow{2}{*}{$\begin{array}{c}2000- \\
2012\end{array}$} & \multirow[t]{2}{*}{11} & 2 & & \multirow[t]{2}{*}{ NR } & \multirow[t]{2}{*}{ Normal } & \multirow{2}{*}{$\begin{array}{l}\text { Epidermoid cysts (6); } \\
\text { Sertoli cell tumour (3) }\end{array}$} & \multirow{2}{*}{$\begin{array}{c}\text { Mixed sex } \\
\text { cord/gonadal stromal } \\
\text { tumour }(2)\end{array}$} & \multirow[t]{2}{*}{ NR } \\
\hline & & & & $\begin{array}{r}1 \text { solit } \\
8 \text { normal cc }\end{array}$ & $\begin{array}{l}\text { testis tm } \\
\text { tralateral testis }\end{array}$ & & & & & \\
\hline $\begin{array}{l}\text { Galosi et } \\
\mathrm{al}^{8}\end{array}$ & $\begin{array}{c}38 \\
(18-68)\end{array}$ & NR & 28 & Normal col & ralateral testis & $\begin{array}{c}9.3(2.5- \\
15)\end{array}$ & $\begin{array}{c}\uparrow \mathrm{b}-\mathrm{HCG} \\
(\mathrm{n}=1)\end{array}$ & $\begin{array}{l}\text { Sertoli cell tumour (2); } \\
\text { Leydig cell tumour (5); } \\
\text { hemorrhagic infiltration (8); } \\
\text { fibrosis (3); angiofibroma (1); } \\
\text { epidermoid cyst (1); normal } \\
\text { parenchyma (1); adenomatoid } \\
\text { tumour (1) }\end{array}$ & $\begin{array}{c}\text { Seminoma (3); } \\
\text { seminoma and } \\
\text { intratubular neoplasia } \\
\text { (3) }\end{array}$ & 3 \\
\hline $\begin{array}{l}\text { Bojanic et } \\
\mathrm{al}^{23}\end{array}$ & $35.3 \pm 7.3$ & $\begin{array}{c}2010- \\
2015\end{array}$ & 28 & Normal col & ralateral testis & $11.4 \pm 3.7$ & Normal & $\begin{array}{l}\text { Leydig cell tumour (5); } \\
\text { Sertoli cell tumour (3); } \\
\text { dermoid cyst (1); fibroses (2); } \\
\text { adenomatoid tumour (3); } \\
\text { segmental infarction (3); } \\
\text { hemangioma (1) }\end{array}$ & $\begin{array}{l}\text { Seminoma (6); } \\
\text { NSGCT (4) }\end{array}$ & NR \\
\hline
\end{tabular}




\section{Testis-sparing surgery}

\begin{tabular}{|c|c|c|c|c|c|c|c|c|c|c|}
\hline Our study & $\begin{array}{c}29.9 \pm 12.5 \\
(2-47)\end{array}$ & $\begin{array}{c}2008- \\
2017\end{array}$ & 13 & 1 & 4 & $\begin{array}{l}14.6 \pm 120 . \\
5 \mathrm{~mm} \\
\text { (range 5- } \\
40 \text { ) }\end{array}$ & $\uparrow \operatorname{AFP}(\mathrm{n}=1)$ & $\begin{array}{l}\text { Leydig cell tumour (1); } \\
\text { adenomatoid tumour (2); } \\
\text { epidermoid cyst (3); } \\
\text { ischemic infarct (1); } \\
\text { sperm granuloma (1); } \\
\text { hyaline changes (1); } \\
\text { tunica albugenia cyst (1) }\end{array}$ & $\begin{array}{c}\text { Embryonal carcinoma } \\
\text { (1); seminoma (1); } \\
\text { seminoma+ } \\
\text { ITGCN(1) }\end{array}$ & 2 \\
\hline
\end{tabular}

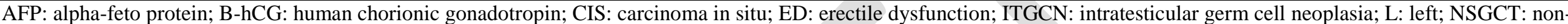
seminoma germ cell tumour; R: right; RT: radiation therapy; US: ultrasound; T: testosterone; TIN: testicular intraepithelial neoplasia; TSS: testis-sparing surgery.

\begin{tabular}{|c|c|c|c|c|c|c|c|c|c|c|}
\hline Study & $\begin{array}{l}\text { Complementary } \\
\text { orchiectomy (n) }\end{array}$ & $\begin{array}{c}\text { Adjuvant } \\
\text { KT (n) }\end{array}$ & $\begin{array}{l}\text { Adjuvant } \\
\text { RT (n) }\end{array}$ & $\begin{array}{c}\text { Local } \\
\text { recurrence }\end{array}$ & $\begin{array}{l}\text { Treatment of } \\
\text { recurrence }\end{array}$ & $\begin{array}{l}\text { Sperm } \\
\text { count }\end{array}$ & $\begin{array}{c}\text { Testosterone } \\
\text { level }\end{array}$ & $\begin{array}{c}\text { Postop } \\
\text { testosterone } \\
\text { supplement }\end{array}$ & $\begin{array}{c}\text { Postop } \\
\text { sexual } \\
\text { function } \\
\end{array}$ & Followup (mos) \\
\hline $\begin{array}{l}\text { Gentile et } \\
\mathrm{al}^{15}\end{array}$ & 2 & No & No & No & No & Normal & Normal & No & Normal & $19.2 \pm 11.5$ \\
\hline $\begin{array}{l}\text { Yaniv } \\
\text { Shilo et } \\
\mathrm{al}^{13}\end{array}$ & 5 & 1 & No & No & No & NA & NA & NA & NA & 48 (range 30-68) \\
\hline $\begin{array}{l}\text { Bojanic et } \\
\mathrm{al}^{22}\end{array}$ & 0 & 10 & No & 7 & $\begin{array}{c}\text { Radical } \\
\text { orchiectomy (5) } \\
\text { Re-do TSS (2) }\end{array}$ & $\begin{array}{c}\text { Azospermia } \\
\text { after surgery } \\
\text { (2) }\end{array}$ & NR & NR & NA & 51 (range 7-178) \\
\hline $\begin{array}{l}\text { Bianjiang } \\
\text { Liu et } \text { al }^{16}\end{array}$ & 2 & No & No & No & No & Normal & Normal & No & Normal & $31.7 \pm 15.8$ \\
\hline $\begin{array}{l}\text { Galosi et } \\
\mathrm{al}^{8}\end{array}$ & 11 & NA & NA & NA & NA & NA & NA & NA & NA & NA \\
\hline $\begin{array}{l}\text { Bojanic et } \\
\mathrm{al}^{23}\end{array}$ & 1 & No & No & 1 & $\begin{array}{c}\text { Radical } \\
\text { orchiectomy (1) }\end{array}$ & NA & NA & NA & NR & $40.9 \pm 20.5$ \\
\hline Our study & No & 1 & 1 & 1 & $\begin{array}{c}\text { Radical } \\
\text { orchiectomy (1) }\end{array}$ & NA & $\begin{array}{l}\text { Normal (10) } \\
\text { Low (3) }\end{array}$ & 2 & $\begin{array}{c}\text { Normal (10) } \\
\text { ED (2) } \\
\text { Preop ED } \\
(1)\end{array}$ & $47.2 \pm 22.5$ \\
\hline
\end{tabular}

